\title{
FAKTOR - FAKTOR YANG MEMPENGARUHI \\ INOVASI ALUMNI DIKLATPIM DALAM MENUNJANG KINERJA \\ ORGANISASI PEMERINTAH DAERAH \\ PROVINSI SULAWESI TENGGARA
}

\section{FACTORS INFLUENCING THE INNOVATION OF THE THREE AND FOUR ALUMNI OF EDUCATION AND TRAINING LEADERSHIP IN SUPPORT- ING THE PERFORMANCE OF REGIONAL GOVERMENT ORGANIZATION IN SOUTH EAST SULAWESI PROVINCE}

\author{
Sahabuddin \\ Widyaiswara Ahli Madya pada Badan Pengembangan Sumber Daya Manusia \\ Provinsi Sulawesi Tenggara \\ E-mail : karaeng71262@gmail.com
}

Naskah diterima tanggal 4 Juni 2020. Naskah direvisi tanggal 14 Juli 2020.

Naskah disetujui tanggal 21 Juli 2020

\begin{abstract}
Abstrak
Keberhasilan suatu organisasi pemerintah daerah Provinsi Sulawesi Tenggara juga dipengaruhi oleh kinerja pegawainya yang memiliki seperangkat kompetensi khusunya Alumni Pendidikan dan Pelatihan Kepemimpinan, baik itu Komptensi Teknis maupun Kompetensi Sosial kultural terlebih lagi Kompetensi Manajerial. Seorang pegawai atau Pejabat Administrator dan Pejabat Pengawas yang telah mengikuti Pelatihan Kepemimpian telah dibekali pengetahuan tentang bagaimana cara berinovasi, membuat suatu perubahan cara kerja untuk keluar dari permasalahan yang ada dalam tugas pokok dan fungsinya tentunya harus memberikan manfaat yang signifikan terhadap kinerja organisasi dimana pegawai tersebut mengabdikan dirinya, keberhasilan semuanya itu dipengaruhi beberapa faktor antara lain faktor Coach, Mentor, Stakeholder dan Dukungan Pemerintah Daerah.
\end{abstract}

.Kata Kunci : Inovasi, Kinerja Organisasi.

Abstract

The success of an organization in local government of Southeast of Sulawesi is influenced by the performance of the employees who have a set of competence, especially the alumni of education and training of leadership, which include technical, socio cultural, and managerial as well. An employee or administrator and supervisory officer who have joined leadership training have been given knowledge about how to innovate, make procedure change to overcome problem which exist in their main tasks and function have to give significant benefit over the organizational performance where the employees devote themselves. The success of those things are influenced by some factors, they are; coaches, mentors, stakeholder and support of the local government.

Keywords : Innovation, organizational performance

\section{PENDAHULUAN}

\section{Latar Belakang}

Perkembangan yang terjadi dalam kehidupan berbangsa dan bernegara saat ini semakin maju dan sulit diprediksi. Ilmu pengetahuan semakin canggih menuntut setiap organisasi untuk berbenah diri menghadapi tantangan dan tututan atas perubahan yang serba sulit diduga, Salah 
satu tantangan yang dihadapi di masa depan adalah untuk menciptakan organisasi yang menuntut pengelolaan sumber daya yang efisien agar bisa berkembang dalam persaingan yang semakin ketat.

Potensi setiap sumber daya manusia yang ada dalam suatu organisasi perangkat daerah (OPD) seharusnya dapat dimanfaatkan dengan sebaik baiknya untuk mampu memberikan hasil kerja yang optimal demi kinerja yang lebih baik. Tercapainya tujuan yang ditetapkan suatu organisasi tidak hanya tergantung pada peralatan yang modern dan mumpuni, sarana dan prasarana yang lengkap, tetapi juga tergantung pada manusia yang menjalankannya untuk menunjang pekerjaannya. Keberhasilan suatu organisasi pemerintah daerah Provinsi Sulawesi Tenggara juga dipengaruhi oleh kinerja individu pegawainya yang memiliki seperangkat kompetensi khusunya Alumni Diklat PIM, baik itu kompetensi teknis maupun kompetensi sosial kultural terlebih lagi kompetensi manajerial.

Sesuai dengan Peraturan Kepala Lembaga Administrasi Negara Nomor 19 Tahun 2015 dan Nomor 20 Tahun 2015 tentang Pedoman Penyelenggaraan Pendidikan dan Pelatihan Kepemimpinan baik itu Kepemimpinan Tingkat III maupun Kepemimpinan Tingkat IV. Kurikulum secara keseluruhan masingmasing tingkatan terdiri atas 5 tahapan pembelajaran. Kelima tahapan pembelajaran tersebut terdiri atas; Pertama, Agenda Penguasaan Diri (Self Mastery) yang diberikan kepada peserta dengan maksud agar peserta dapat mengaktualisasikan wawasan kebangsaan, semangat nasionalisme, akuntabilitas dan etika. Kedua, Agenda Diagnosa Perubahan (Diagnostic Reading) diberikan kepada peserta agar mampu mengidentifikasi akar permasalahan dalam mengelola tugas dan fungsinya serta dapat menyusun solusi pemecahannya dalam bentuk inovasi yang dikenal dengan sebutan Proyek Perubahan. Dalam agenda ini peserta dibekali dengan mata diklat diagnosa perubahan dan isu-isu strategis. Ketiga, agenda inovasi diberikan agar peserta mampu merancang pengembangan potensi dirinya dalam melakukan inovasi terkait pengelolaan tugas dan fungsinya, membangun budaya kerja untuk efektifitas kepemimpinannya dan mengadopsi dan mengadaptasi keunggulan pengelolaan tugas dan fungsi organisasi lain ke unit kerjanya. Keempat, Agenda Tim Efektif. Kelima, Agenda Proyek Perubahan. Khusus agenda inovasi diberikan kepada peserta Diklatpim dengan tujuan agar peserta mampu merancang pengembangan potensi dirinya, melakukan inovasi terkait pengelolaan tugas dan fungsi pada unit organisasinya, membangun budaya kerja untuk efektifitas kepemimpinannya dan mengadopsi dan mengadaptasi keunggulan pengelolaan tugas dan fungsi organisasi lain ke unit kerjanya. Dalam melahirkan inovasi yang berkualitas oleh peserta Diklatpim sangat ditentukan oleh peran coach dan mentor. Persoalan yang muncul adalah adakah kemampuan yang dimiliki oleh coach dan mentor peserta Diklatpim yang merupakan atasan langsung dari alumni untuk melahirkan inovasi terkait permasalahan yang ada di tugas dan fungsinya dalam bentuk proyek perubahan sehingga bisa mendorong dalam upaya meningkatnya kinerja, melihat lebih jauh sehingga mendorong timbulnya inovasi berupa proyek perubahan yang relevan dengan permasalahan yang ada di dalam institusinya, dan bisa mendorong meningkatnya kinerja organisasi perangkat daerah Provinsi Sulawesi Tenggara.

Seorang pegawai atau Pejabat Struktural eselon III dan eselon IV yang telah mengikuti Pendidikan dan Pelatihan Kepemimpinan (Diklatpim) telah dibekali pengetahuan tentang bagaimana cara berinovasi, membuat suatu perubahan cara kerja untuk keluar dari permasalahan yang ada dalam tugas pokok dan fungsinya tentunya harus memberikan manfaat yang signifikan terhadap kinerja organisasi dimana pegawai tersebut mengabdikan dirinya. Inovasi peserta Diklatpim tersebut dikenal sebagai Proyek Perubahan, sangat menentukan kelulusan peserta yang memiliki bobot $60 \%$, di samping kriteria lain seperti penerapan kemampuan 
memimpin dan menggerakkan pemangku kepentingan (Stakeholder) yang terkait dengan pelaksanaan tugasnya. Di sisi lain, keberlanjutan inovasi dalam merealisasikan tujuan jangka menengah dan panjang sangat ditentukan oleh dukungan stakeholder dan dukungan kebijakan pemerintah daerah khusunya penyediaan anggaran yang dibutuhkan.

\section{Rumusan Masalah}

Berdasarkan gambaran latar belakang yang telah dikemukakan di atas, dalam penelitian ini yang menjadi rumusan masalah penelitian adalah:

1. Faktor - faktor apa saja yang mempengaruhi inovasi alumni Diklatpim dalam mendukung kinerja organisasi pemerintah daerah Provinsi Sulawesi Tenggara?

2. Dari beberapa faktor yang berpengaruh, faktor apa yang paling berpengaruh?

3. Seberapa besar pengaruh yang ditimbulkan oleh faktor-faktor tersebut, sehingga dapat mendukung kinerja organisasi pemerintah daerah?

\section{Tujuan Penelitian}

Berdasarkan latar belakang penulisan dan rumusan masalah yang telah dikemukakan di atas, maka tujuan yang ingin dicapai dalam penelitian ini adalah mengetahui faktor - faktor apa saja yang berpengaruh dalam menentukan keberhasilan inovasi alumni Diklatpim terhadap kinerja organisasi perangkat daerah Provinsi Sulawesi Tenggara.

Hipotesis

H1 : Mentor memiliki pengaruh positif terhadap adanya inovasi

$\mathrm{H} 2$ : Coach memiliki pengaruh positif terhadap inovasi

H3 : Stakeholders memiliki pengaruh positif terhadap inovasi

H4 : Dukungan pemerintah daerah memiliki pengaruh positif terhadap inovasi

\section{TINJAUAN PUSTAKA}

Menurut Mangkunegara (2001:67), Kinerja adalah hasil kerja yang secara kualitas dan kuantitas yang telah dicapai oleh seorang karyawan atau pegawai dalam mengemban tugasnya sesuai dengan tanggung jawab yang telah diberikan kepadanya. Yang dimaksud dengan kualitas di sini adalah dilihat dari segi kebersihan, kehalusan dan ketelitian dalam menjalankan tugas dan pekerjaannya. Sedangkan, yang dimaksud dengan kuantitas itu dilihat dari banyaknya jumlah pekerjaan yang harus diselesaikan oleh pegawai atau karyawan tersebut.

Inovasi adalah suatu penemuan baru yang berbeda dari yang sudah ada atau yang sudah dikenal sebelumnya.orang atau wirausahawan yang slalu berinovasi, maka ia dapat dikatakan sebagai seorang wirausahwan yang inovatif. Seseorang yang inovatif akan selalu berupaya melakukan perbaikan, menyajikan sesuatu yang baru/unik yang berbeda dengan yang sudah ada. Inovatif juga merupakan sikap penting bagi yang hendaknya dimiliki oleh seorang wirausahawan. Wirausahawan yang selalu melakukan inovasi dalam usahanya, maka keuntungan dan kesuksesan akan ia dapat. Inovatif merupakan implikasi dari karakteristik wirausahawan yang mampu membawa perubahan pada lingkungan sekitarnya. Inovatif secara tidak langsung menjadi sifat pembeda antara wirausahawan dengan orang biasa maupun pengusaha.

Seorang pegawai yang memiliki kreativitas akan selalu memikirkan untuk melakukan sesuatu yang berbeda, tidak seperti yang dipikirkan dan dilakukan oleh kebanyakan orang. Pengertian inovasi di bidang pelayanan publik merupakan ide kreatif teknologi atau cara baru dalam teknologi pelayanan atau memperbarui yang sudah ada di bidang teknologi pelayanan atau menciptakan terobosan atau penyederhanaan di bidang aturan, pendekatan, prosedur, metode, maupun struktur organisasi pelayanan yang manfaatnya hasil mempunyai nilai tambah baik dari segi kuantitas maupun kualitas pelayanan.

\section{Faktor Penunjang Inovasi}

Faktor Penunjang Inovasi Menurut Everett M. Rogers $(2003 ; 219)$ Inovasi dapat ditunjang oleh beberapa faktor 
pendukung seperti:

1. Adanya keinginan untuk merubah diri, dari tidak bisa menjadi bisa dan dari tidak tahu menjadi tahu.

2. Adanya kebebasan untuk berekspresi.

3. Adanya pembimbing yang berwawasan luas dan kreatif.

4. Tersedianya sarana dan prasarana.

5. Kondisi lingkungan yang harmonis, baik lingkungan keluarga, pergaulan, maupun sekolah.

Disamping faktor-faktor tersebut di atas, faktor penunjang lainnya adalah :

1. Adanya peserta yang memahami tugas pokok dan fungsinya serta memiliki kemampuan mamilih inovasi yang tepat terkait dengan pelaksanaan tugasnya.

2. Mentor yang memiliki kometmen terhadap adanya perubahan.

3. Coach yang mampu membimbing dan mengarahkan peserta diklat untuk menemukan inovasi baru yang terkait dengan permasalahan tugas pokok dan fungsi peserta.

4. Stakeholders yang berperan aktif dalam memberikan dukungan positif demi kemajuan organisasi dan kepentingan masyarakat.

5. Pemerintah daerah yang senantiasa memberikan dukungan termasuk dukungan penyediaan anggaran yang dibutuhkan untuk keberlanjutan inovasi tersebut.

Coach adalah orang yang melakukan proses coaching. Seorang coach akan melaksanakan proses coaching hanya akan bertanya dan menggali permasalahan coachee-nya bahkan tidak memberikan saran dan masukan, semua ide dan pemikiran berasal dari coachee-nya. Coach hanya membantu coachee-nya berpikir, menimbulkan insight dan menstrukturkan pemikiran mereka di samping itu memastikan si coachee-nya melakukan apa yang telah dia pikirkan dan katakan.

Coach sangat berperan dalam menemu-kenali masalah yang ada dalam pelaksanaan tugas dan fungsi peserta Diklatpim dengan bertanya kepada coachee-nya dan mendengar apa yang dikatakan oleh coachee-nya untuk diangkat sebagai solusi dalam bentuk inovasi atau proyek perubahan. Peran coach dapat membimbing coachee/peserta Diklatpim untuk menemukan inovasi yang tepat sesuai dengan permasalahan yang terjadi dalam pelaksanaan tugas dan fungsi peserta Diklatpim.

Secara bahasa, Mentor berasal dari bahasa Inggris yang artinya penasehat. Mentor adalah seorang yang penuh kebijaksanaan, pandai mengajar, mendidik, membimbing, membina, melatih dan menangani orang lain. Mentor yang sekaligus atasan langsung alumni harus memahami tugas dan fungsinya sebagai mentor. Salah satu tugas mentor adalah mengarahkan peserta Diklatpim baik itu Diklatpim III maupun Diklatpim IV dalam menentukan tema atau solusi terkait dengan masalah yang ada di dalam pelaksanaan tugasnya sebagai Aparatur Sipil Negara yang diberi tugas dan tanggung jawab sebagai pejabat di lingkungan kerjanya. Masalah tersebut dapat diperoleh melalui identifikasi pelaksanaan tugas yang sudah dilaksanakan dengan membandingkan pelaksanaan tugas yang seharusnya menurut ketentuan yang berlaku. Adanya ketidaksamaan antara yang telah dilaksanakan dengan yang seharusnya, ini memberikan tanda bahwa ada masalah dalam pelaksanaan tugas tersebut. Dari beberapa masalah yang ada, dipilih masalah yang prioritas untuk dicari solusi pemecahannya sebagai Inovasi yang dikenal sebagai Proyek Perubahan.

Menurut Freeman (1998; 75-88) Stakeholders adalah semua pihak di dalam masyarakat, baik itu individu, komunitas atau kelompok masyarakat yang memiliki hubungan dan kepentingan terhadap sebuah organisasi yang memiliki permasalahan yang sedang diangkat, stakeholders adalah bagian penting dari organisasi yang memiliki arti terjemahan bahasa Indonesia sebagai pemangku kepentingan atau pihak yang berkepentingan.

Secara umum, stakeholders dapat dikelompokkan berdasarkan kekuatan, posisi dan pengaruhnya. Adapun 
klasifikasi stakeholders adalah sebagai berikut::

a. Stakeholder utama (Primer) yang berhubungan langsung dengan pembuatan kebijakan, program dan anggaran, mereka merupakan penentu utama dalam pengambilan keputusan.

b. Stakeholder Pendukung (Sekunder) yaitu pihak yang berkaitan langsung terhadap suatu kebijakan, namun stakeholders sekunder punya perhatian dan kepedulian sehingga ikut menyuarakan pendapat yang bisa mempengaruhi sikap stakeholders utama.

c. Stakeholder Kunci yaitu eksekutif berdasarkan levelnya (legislative dan instansi) yang memiliki wewenang secara legal untuk mengambil keputusan.

Dalam menjamin keberlanjutan inovasi alumni Diklatpim dukungan stakeholders sangat dibutuhkan utamanya pencapaian tujuan jangka menengah dan tujuan jangka panjang, besar kecilnya dukungan yang bersumber dari stakeholder mempengaruhi keberhasilan target tujuan yang ditetapkan.

Dukungan Pemda adalah fasilitas yang diberikan kepada Aparatur Sipil Negara atau Calon Pegawai Negeri Sipil agar dapat bekerja optimal dan memperlihatkan prestasi sesuai tugas pokok dan fungsinya sehingga dapat berkontribusi terhadap kinerja penyelenggaraan pemerintahan daerah. Fasilitas tersebut dapat berupa: sarana dan prasarana kerja, pemberian penghargaan dan hak peningkatan karir, dan tak kalah pentingnya adalah dukungan pemberian anggaran yang sangat menentukan keberlanjutan sebuah Proyek Perubahan. Di sisi lain jika dukungan itu tidak dapat diperoleh, maka dapat menghambat keberlangsung Proyek Perubahan utamanya pencapaian tujuan jangka menengah dan tujuan jangka panjang.

Tidak semua pemimpin organisasi mampu menciptakan lingkungan yang ramah untuk mengembangkan inovasi ada beberapa kegagalan yang sering terjadi yang dilakukan oleh pemimpin organisasi pemerintah daerah diantaranya; gagal menetapkan prioritas inovasi, gagal menetapkan strategi dan gagal menunjukkan contohnya (Munro, 2015).

\section{METODE PENELITIAN}

\section{Lokasi dan Waktu Penelitian}

Penelitian ini dilaksanakan mualai tanggal 1 Januari s.d 29 Februari 2020 pada Pegawai Organisasi Perangkat Daerah Lingkup Provinsi Sulawesi Tenggara yakni Pejabat Struktural eselon III (Administrator) dan Pejabat Struktural eselon IV ( Pengawas) yang telah mengikuti Diklatpin III dan IV pola baru yang yang menghasilkan inovasi yang dikenal dengan Proyek Perubahan. Hal tersebut ditengarai sangat menentukan pencapaian Visi-Misi Organisasi Pemerintah Daerah dimana pegawai tersebut melaksanakan tugas.

\section{Sifat Penelitian}

Dilihat dari sifatnya penelitian ini bersifat deskriptif analisis, karena memberikan gambaran tentang presentase besarnya pengaruh faktor - faktor terhadap keberhasilan inovasi alumni Diklatpim dalam mendukung Kinerja Organisasi Pemerintah Daerah Provinsi Sulawesi Tenggara.

\section{Teknik Pengumpulan Data}

Teknik pengumpulan data melalui penyebaran angket/kuesioner yang terdiri dari daftar pertanyaan yang disusun secara sistematik dan ditanyakan pada responden terpilih dan dilanjukan dengan wawancara untuk menggali informasi dan mendapatkan data yang berkaitan dengan faktor - faktor yang mempengaruhi inovasi alumni.

\section{Metode Analisis Data \\ Populasi dan Sampel Penelitian}

Populasi dalam penelitian ini adalah seluruh pegawai Organisasi Perangkat Daerah Lingkup Provinsi Sulawesi Tenggara yang telah mengikuti Diklatpim III dan IV dalam kurung waktu 2017 dan 2018. Penentuan jumlah Sampel dalam penelitian ini dengan menggunakan rumus 
Slovin yang dikutip dari buku Wiratna Sujarweni (2014: 16) yaitu sebagai berikut :

$$
\begin{aligned}
& \mathrm{N}= \\
& \left(1+\mathrm{N} \cdot(\mathrm{e})^{2}\right)
\end{aligned}
$$

keterangan :

$n \quad$ : Ukuran sampel

$N$ : Ukuran Populasi

$e$ Tingkat Kesalahan yang

- dinyatakan dalam \% atau toleransi

ketidaktelitian dalam menentukan banyaknya responden

\section{Teknik Analisa Data}

Teknik analisis data yang digunakan dalam penelitian ini adalah analisis deskripsi hubungan faktor- faktor yang berpengaruh terhadap inovasi alumni Diklatpim dalam mendukung kinerja Organisasi Perangkat Daerah Provinsi Sulawesi Tenggara yang didahului dengan analisis Pengaruh dengan menggunakan SPSS versi 23.

\section{HASIL dan PEMBAHASAN}

\section{Deskripsi Karasteristik Responden}

Responden penelitian ini adalah pegawai negeri sipil pada Satuan Kerja Perangkat Daerah Provinsi Sulawesi Tenggara yang telah mengikti Diklatpim III dan IV. Uraian ini tentang karakteristik responden bertujuan untuk mendeskripsikan karakter pegawai yang menjadi responden berdasarkan jenis kelamin, pendidikan, usia dan diklat yang pernah diikuti. Hal ini sejalan dengan Berman dan Evans (2007) yang dikutip oleh Rohman (2009) menyatakan bahwa karakteristik personal mempengaruhi keputusan dan tindakan yang dilakukan seseorang dan mempengaruhi pilihan. Berdasarkan jawaban kuesioner yang disebar pada 127 Responden yang merupakan sampel penelitian ini, diperoleh gambaran komposisi alumni berdasarkan pendidikan, usia, jenis kelamin, jabatan dan Diklatpim yang pernah diikuti dapat dilihat pada tabel 3.1 pada bagian halaman lain.

\section{Deskriptif Variabel Hasil Penelitian}

Deskriptif variabel penelitian bertujuan untuk mendeskriptifkan variabel (peran mentor, peran coach, dukungan stakeholder, dukungan Pemda dan inovasi) berdasarkan persepsi responden sehingga dapat diperoleh informasi tentang kondisi variabel itu berada pada kondisi penilaian dimana rumus statistik yang

$$
C=\frac{X n-X 1}{k}
$$

digunakan adalah :

Keterangan :

$\mathrm{C}$ : Perkiraan besarnya kelas (class size)

$\mathrm{K}$ : Banyaknya kelas

$\mathrm{Xn}$ : Nilai observasi terbesar

X1 : Nilai observasi terkecil

Sumber : Supranto (2011:64)

Jadi perhitungannya adalah :

$$
\begin{aligned}
C & =\frac{4-1}{4} \\
& =0,75
\end{aligned}
$$

Setelah besarnya interval kelas diketahui kemudian dibuat rentang skala rerata (mean) dari hasil persepsi responden dengan kriteria sebagaimana pada tabel 3.1 berikut ini:

Tabel 3.2. Kriteria Deskriptif Variabel Penelitian

\begin{tabular}{|c|c|}
\hline $\begin{array}{c}\text { Rerata } \\
\text { (Mean })\end{array}$ & $\begin{array}{c}\text { Kategori Persepsi } \\
\text { Responden }\end{array}$ \\
\hline $1,00-1,74$ & Sangat Tidak Baik \\
\hline $1,75-2,49$ & Tidak Baik \\
\hline $2,50-3,24$ & Baik \\
\hline $3,24-4,00$ & Sangat Baik \\
\hline
\end{tabular}

Sumber : Supranto (2011:64) diadaptasi oleh penulis 
Tabel 3.1. Deskripsi Karakteristik Responden

\begin{tabular}{|c|c|c|c|}
\hline No. & Keterangan & $\begin{array}{l}\text { Jumlah } \\
\text { (orang) }\end{array}$ & $\begin{array}{l}\text { Prosentase } \\
(\%)\end{array}$ \\
\hline A. & \multicolumn{3}{|l|}{ Jenis Kelamin } \\
\hline & Laki-Laki & 72 & 56,69 \\
\hline & Perempuan & 55 & 43,31 \\
\hline & Jumlah & 127 & 100 \\
\hline $\bar{B}$. & \multicolumn{3}{|l|}{ Pendidikan } \\
\hline & $\overline{\mathrm{S} 1}$ & 53 & 41,73 \\
\hline & $\overline{\mathrm{S} 2}$ & 70 & 55,12 \\
\hline & S3 & 4 & 3,15 \\
\hline & Jumlah & 127 & 100 \\
\hline C. & \multicolumn{3}{|l|}{ Us i a } \\
\hline & $25-35$ Tahun & 7 & 5,51 \\
\hline & $36-55$ Tahun & 106 & 83,46 \\
\hline & $>55$ Tahun & 14 & 11,02 \\
\hline & Jumlah & 127 & 100 \\
\hline D. & \multicolumn{3}{|l|}{ Diklat yang diikuti } \\
\hline & Diklatpim III & 54 & 42,52 \\
\hline & Diklatpim IV & 73 & 57,48 \\
\hline & Jumlah & 127 & 100 \\
\hline E. & \multicolumn{3}{|l|}{ Jabatan saat ini } \\
\hline & Eselon III & 24 & 18,90 \\
\hline & Eselon IV & 103 & 81,10 \\
\hline & Jumlah & 127 & 100 \\
\hline
\end{tabular}

Sumber : Data Primer, diolah oleh penulis

Tabel 3.2 menunjukkan makna kategorik dalam melakukan interpretasi hasil penelitian ini berdasarkan skor jawaban responden. Alasan yang mendasari responden diberikan kebebasan untuk memberikan penilaian secara objektif berdasarkan apa yang dilihat, didengar dan dirasakan selama menjadi Alumni Diklatpim Perangkat Daerah Provinsi Sulawesi Tenggara.

Gambaran data tanggapan responden dari hasil penelitian mengenai keempat variabel laten yang diteliti dengan menggunakan nilai rata-rata skor pernyataan responden dapat diuraikan sebagai berikut :

\section{Variabel Peran Mentor}

Berdasarkan hasil penelitian yang diperoleh melalui kuesioner, maka kondisi objektif untuk variabel peran mentor dilihat pada Tabel 3.3.berikut ini. 
Tabel 3.3. Distribusi Jawaban Responden Terhadap Variabel Peran Mentor

\begin{tabular}{|c|c|c|c|c|c|c|c|c|c|}
\hline \multirow{3}{*}{$\begin{array}{l}\text { Item } \\
\text { (Butir) }\end{array}$} & \multicolumn{8}{|c|}{ Frekuensi Jawaban Responden (f) dan Persentase (\%) } & \multirow{3}{*}{ Rata-rata } \\
\hline & \multicolumn{2}{|c|}{ SS (4) } & \multicolumn{2}{|c|}{$\mathrm{S}(3)$} & \multicolumn{2}{|c|}{ TS (2) } & \multicolumn{2}{|c|}{ STS (1) } & \\
\hline & $\mathrm{F}$ & $\%$ & $\mathrm{~F}$ & $\%$ & $\mathrm{f}$ & $\%$ & $\mathrm{~F}$ & $\%$ & \\
\hline $\mathrm{X}_{1.1}$ & 57 & 44,88 & 40 & 31,50 & 21 & 16,54 & 9 & 7,09 & 3,14 \\
\hline $\mathrm{X}_{1.2}$ & 56 & 44,09 & 37 & 29,13 & 25 & 19,69 & 9 & 7,09 & 3,10 \\
\hline $\mathrm{X}_{1.3}$ & 56 & 44,09 & 33 & 25,98 & 25 & 19,69 & 13 & 10,24 & 3,04 \\
\hline$\overline{X_{1.4}}$ & 55 & 43,31 & 36 & 28,35 & 25 & 19,69 & 11 & 8,66 & 3,06 \\
\hline $\mathrm{X}_{1.5}$ & 60 & 47,24 & 29 & 22,83 & 22 & 17,32 & 16 & 12,60 & 3,05 \\
\hline \multicolumn{9}{|c|}{ Rata-Rata Skor Variabel Peran Mentor } & 3,08 \\
\hline
\end{tabular}

Sumber: Data Primer diolah Tahun 2020

Tabel 3.4. Distribusi Jawaban Responden Terhadap Variabel Peran Coach

\begin{tabular}{|c|c|c|c|c|c|c|c|c|c|}
\hline \multirow{3}{*}{$\begin{array}{l}\text { Item } \\
\text { (Butir) }\end{array}$} & \multicolumn{8}{|c|}{ Frekuensi Jawaban Responden (f) dan Persentase (\%) } & \multirow{3}{*}{ Rata-rata } \\
\hline & \multicolumn{2}{|c|}{ SS (4) } & \multicolumn{2}{|c|}{$\mathrm{S}(3)$} & \multicolumn{2}{|c|}{ TS (2) } & \multicolumn{2}{|c|}{ STS (1) } & \\
\hline & $\mathrm{F}$ & $\%$ & $\bar{F}$ & $\%$ & $\mathrm{f}$ & $\%$ & $\bar{F}$ & $\%$ & \\
\hline $\mathrm{X}_{2.1}$ & 57 & 44,88 & 39 & 30,71 & 21 & 16,54 & 10 & 7,87 & 3,13 \\
\hline $\mathrm{X}_{2.2}$ & 69 & 54,33 & 28 & 22,05 & 19 & 14,96 & 11 & 8,66 & 3,22 \\
\hline $\mathrm{X}_{2.3}$ & 71 & 55,91 & 26 & 20,47 & 21 & 16,54 & 9 & 7,09 & 3,25 \\
\hline $\mathrm{X}_{2.4}$ & 62 & 48,82 & 32 & 25,20 & 21 & 16,54 & 12 & 9,45 & 3,13 \\
\hline $\mathrm{X}_{2.5}$ & 67 & 52,76 & 28 & 22,05 & 22 & 17,32 & 10 & 7,87 & 3,20 \\
\hline \multicolumn{9}{|c|}{ Rata-Rata Skor Variabel Peran Coach } & 3,19 \\
\hline
\end{tabular}

Sumber: Data Primer diolah Tahun 2020

Tabel 3.5. Distribusi Jawaban Terhadap Variabel Dukungan Stakeholder

\begin{tabular}{|c|c|c|c|c|c|c|c|c|c|}
\hline \multirow{2}{*}{$\begin{array}{c}\text { Item } \\
\text { (Butir) }\end{array}$} & \multicolumn{6}{|c|}{ Frekuensi Jawaban Responden (f) dan Persentase (\%) } & \multirow{2}{*}{$\begin{array}{c}\text { Rata- } \\
\text { rata }\end{array}$} \\
\cline { 2 - 10 } & $\mathrm{SS}(4)$ & \multicolumn{2}{|c|}{$\mathrm{S}(3)$} & \multicolumn{2}{|c|}{ TS (2) } & \multicolumn{2}{|c|}{ STS (1) } \\
\hline $\mathrm{X}_{3.1}$ & 66 & 51,97 & 32 & 25,20 & 20 & 15,75 & 9 & 7,09 & 3,22 \\
\hline $\mathrm{X}_{3.2}$ & 72 & 56,69 & 25 & 19,69 & 19 & 14,96 & 11 & 8,66 & 3,24 \\
\hline $\mathrm{X}_{3.3}$ & 69 & 54,33 & 28 & 22,05 & 19 & 14,96 & 11 & 8,66 & 3,22 \\
\hline \multicolumn{8}{|c|}{ Rata-Rata Skor Variabel Dukungan Stakeholder } & \multirow{2}{*}{3,23} \\
\hline
\end{tabular}

Sumber: Data Primer diolah Tahun 2020

Tabel 3.5. Distribusi Jawaban Terhadap Variabel Dukungan Stakeholder

\begin{tabular}{|c|c|c|c|c|c|c|c|c|c|}
\hline \multirow{3}{*}{$\begin{array}{l}\text { Item } \\
\text { (Butir) }\end{array}$} & \multicolumn{8}{|c|}{ Frekuensi Jawaban Responden (f) dan Persentase (\%) } & \multirow{3}{*}{ Rata-rata } \\
\hline & \multicolumn{2}{|c|}{ SS (4) } & \multicolumn{2}{|c|}{$\mathrm{S}(3)$} & \multicolumn{2}{|c|}{ TS (2) } & \multicolumn{2}{|c|}{ STS (1) } & \\
\hline & $\mathrm{F}$ & $\%$ & $\overline{\mathrm{F}}$ & $\%$ & $\overline{\mathrm{F}}$ & $\%$ & $\mathrm{~F}$ & $\%$ & \\
\hline $\mathrm{X}_{4.1}$ & 63 & 49,61 & 34 & 26,77 & 21 & 16,54 & 9 & 7,09 & 3,19 \\
\hline $\mathrm{X}_{4.2}$ & 58 & 45,67 & 34 & 26,77 & 22 & 17,32 & 13 & 10,24 & 3,08 \\
\hline $\mathrm{X}_{4.3}$ & 63 & 49,61 & 34 & 26,77 & 21 & 16,54 & 9 & 7,09 & 3,19 \\
\hline $\mathrm{X}_{4.4}$ & 63 & 49,61 & 34 & 26,77 & 21 & 16,54 & 9 & 7,09 & 3,19 \\
\hline \multicolumn{9}{|c|}{ Rata-Rata Skor Variabel Dukungan Pemda } & 3,16 \\
\hline
\end{tabular}

Sumber: Data Primer diolah Tahun 2020 
Pada tabel 3.3.di atas dapat diketahui bahwa variabel peran mentor pada Alumni Diklatpim Perangkat Daerah Provinsi Sulawesi Tenggara berada pada kategori baik yang ditunjukan dengan nilai rata-rata skor penilaian untuk variabel peran mentor sebesar 3,08.

Hal ini menunjukkan bahwa Alumni Diklatpim Perangkat Daerah Provinsi Sulawesi Tenggara merasa peran mentor sangat menentukan kualitas dari Alumni Diklatpim Perangkat Daerah Provinsi Sulawesi Tenggara. Namun masih ada sebagian responden yang menyatakan tidak setuju dan sangat tidak setuju terhadap item pernyataan dari variabel peran mentor.

Faktor penyebab adanya responden yang memilih jawaban tidak setuju dan sangat tidak setuju dikarenakan masih adanya Alumni Diklatpim Perangkat Daerah Provinsi Sulawesi Tenggara yang mempersepsikan rendah terhadap variabel peran mentor.

\section{Variabel Peran Coach}

Berdasarkan hasil penelitian yang diperoleh melalui kuesioner, maka kondisi objektif untuk variabel peran coach dilihat pada Tabel 3.4.

Dari tabel tersebut dapat diketahui bahwa variabel peran coach pada Alumni Diklatpim Perangkat Daerah Provinsi Sulawesi Tenggara berada pada kategori baik yang ditunjukan dengan nilai rata-rata skor penilaian untuk variabel peran coach sebesar 3,19. Hal ini menunjukkan bahwa Alumni Diklatpim Perangkat Daerah Provinsi Sulawesi Tenggara merasa peran coach sangat menentukan kualitas dari Alumni Diklatpim Perangkat Daerah Provinsi Sulawesi Tenggara. Namun masih ada sebagian responden yang menyatakan tidak setuju dan sangat tidak setuju terhadap item pernyataan dari variabel peran coach.

\section{Variabel Dukungan Stakeholder}

Berdasarkan hasil penelitian yang diperoleh melalui kuesioner, maka kondisi objektif untuk variabel dukungan stakeholderdilihat pada Tabel 4.4.
Seperti yang terlihat pada tabel 3.5, variabel dukungan stakeholder pada Alumni Diklatpim Perangkat Daerah Provinsi Sulawesi Tenggara berada pada kategori baik yang ditunjukan dengan nilai rata-rata skor penilaian untuk variabel peran stakeholder sebesar 3,23. Hal ini menunjukkan bahwa Alumni Diklatpim Perangkat Daerah Provinsi Sulawesi Tenggara merasa dukungan stakeholder sangat menentukan kualitas dari Alumni Diklatpim Perangkat Daerah Provinsi Sulawesi Tenggara. Namun masih ada sebagian responden yang menyatakan tidak setuju dan sangat tidak setuju terhadap item pernyataan dari variabel dukungan stakeholder.

\section{Variabel Dukungan Pemda}

Kondisi objetif untuk variabel dukungan Pemda seperti terlihat pada tabel 3.6 menyimpulkan bahwa variabel dukungan Pemda pada Inovasi Alumni Diklatpim Perangkat Daerah Provinsi Sulawesi Tenggara berada pada kategori baik yang ditunjukan dengan nilai rata-rata skor penilaian untuk variabel dukungan Pemda sebesar 3,16. Hal ini menunjukkan bahwa Alumni Diklatpim Perangkat Daerah Provinsi Sulawesi Tenggara merasa dukungan Pemda sangat menentukan kualitas dari Alumni Diklatpim Perangkat Daerah Provinsi Sulawesi Tenggara. Namun masih ada sebagian responden yang menyatakan tidak setuju dan sangat tidak setuju terhadap item pernyataan dari variabel dukungan Pemda.

\section{PEMBAHASAN}

Pengaruh Peran Mentor, Peran Coach, Dukungan Stakeholder dan Dukungan Pemda Terhadap Inovasi

Berdasarkan hasil analisis data dalam penelitian ini, diperoleh nilai koefisien regresi yang menunjukkan pengaruh peran mentor, peran coach, dukungan stakeholder dan dukungan pemda terhadap inovasi Alumni Diklatpim dalam mendukung kinerja organisasi Perangkat Daerah Provinsi Sulawesi Tenggara yang positif dan signifikan. Ini 
menunjukkan bahwa peningkatan peran mentor, peran coach, dukungan stakeholder dan dukungan Pemda yang diberikan akan dapat meningkatkan inovasi Alumni Diklatpim sebesar 0,207 dalam mendukung kinerja organisasi Perangkat Daerah Provinsi Sulawesi Tenggara. Alumni Diklatpim Perangkat Daerah Provinsi Sulawesi Tenggara peran mentor, peran coach, dukungan stakeholder dan dukungan Pemda sangat baik yang akan berimplikasi pada peningkatan inovasi Alumni Diklatpim dalam mendukung kinerja organisasi Perangkat Daerah Provinsi Sulawesi Tenggara.

Salah satu tugas mentor adalah mengarahkan peserta Diklatpim baik itu Diklatpim III maupun Diklatpim IV dalam menentukan tema atau solusi terkait dengan masalah yang ada di dalam pelaksanaan Tugasnya sebagai aparatur sipil negara yang diberi tugas dan tanggung jawab sebagai pejabat dilingkungan kerjanya.

Masalah tersebut dapat diperoleh melalui identifikasi pelaksanaan tugas yang sudah dilaksanakan dengan membandingkan pelaksanaan tugas yang seharusnya menurut ketentuan yang berlaku. Adanya ketidaksamaan antara yang telah dilaksanakan dengan yang seharusnya, ini memberikan tanda bahwa ada masalah dalam pelaksanaan tugas tersebut. Dari beberapa masalah yang ada, dipilih masalah yang prioritas untuk dicari solusi pemecahannya sebagai inovasi yang dikenal sebagai proyek perubahan.

Coach sangat berperan dalam menemu-kenali masalah yang ada dalam pelaksanaan tugas dan fungsi peserta Diklatpim dengan bertanya kepada coachee-nya dan mendengar apa yang dikatakan oleh coachee-nya untuk diangkat sebagai solusi dalam bentuk inovasi atau proyek perubahan. Peran Coach dapat membimbing coachee/peserta Diklatpim untuk menemukan inovasi yang tepat sesuai dengan permasalahan yang terjadi dalam pelaksanaan tugas dan fungsi peserta Diklatpim.

Stakeholders adalah semua pihak di dalam masyarakat, baik itu individu, komunitas atau kelompok masyarakat yang memiliki hubungan dan kepentingan terhadap sebuah organisasi yang memiliki permasalahan yang sedang diangkat. Stakeholders adalah bagian penting dari organisasi yang memiliki arti terjemahan bahasa Indonesia sebagai pemangku kepentingan atau pihak yang berkepentingan.

Dalam menjamin keberlanjutan inovasi Alumni Diklatpim dukungan stakeholders sangat dibutuhkan utamanya pencapaian tujuan jangka menengah dan tujuan jangka panjang, besar kecilnya dukungan yang bersumber dari stakeholder mempengaruhi keberhasilan target tujuan yang ditetapkan.

Dukungan Pemda adalah fasilitas yang diberikan kepada Aparatur Sipil Negara atau Calon Pegawai Negeri Sipil agar dapat bekerja optimal dan memperlihatkan prestasi sesuai Tugas Pokok dan Fungsinya sehingga dapat berkontribusi terhadap kinerja penyelenggaraan pemerintahan daerah. Fasilitas tersebut dapat berupa: sarana dan prasarana kerja, pemberian penghargaan dan hak peningkatan karir, dan tak kalah pentingnya adalah dukungan pemberian anggaran yang sangat menentukan keberlanjutan sebuah Proyek Perubahan.

\section{Pengaruh Peran Mentor Terhadap Inovasi}

Berdasarkan hasil analisis data dalam penelitian ini, diperoleh nilai koefisien regresi yang menunjukkan pengaruh peran mentor terhadap inovasi Alumni Diklatpim dalam mendukung kinerja organisasi Perangkat Daerah Provinsi Sulawesi Tenggara yang bertanda positif berdasarkan nilai koefisen regresi sebesar 0,47. Ini menunjukkan bahwa peningkatan peran mentor akan dapat mempengaruhi inovasi Alumni Diklatpim dalam mendukung kinerja organisasi Perangkat Daerah Provinsi Sulawesi Tenggara. Arah dan signifikansi pengaruh peran mentor terhadap inovasi Alumni Diklatpim dalam mendukung kinerja organisasi Perangkat Daerah Provinsi Sulawesi Tenggara tersebut mengindikasikan bahwa peran mentor 
sebagai salah satu elemen yang dapat dikelola oleh manajemen yang memiliki pengaruh signifikan terhadap inovasi alumni Diklatpim dalam mendukung kinerja organisasi perangkat daerah Provinsi Sulawesi Tenggara.

Salah satu tugas mentor adalah mengarahkan peserta Diklatpim baik itu Diklatpim III maupun Diklatpim IV dalam menentukan tema atau solusi terkait dengan masalah yang ada di dalam pelaksanaan Tugasnya sebagai Aparatur Sipil Negara yang diberi tugas dan tanggung jawab sebagai pejabat di lingkungan kerjanya. Masalah tersebut dapat diperoleh melalui identifikasi pelaksanaan tugas yang sudah dilaksanakan dengan membandingkan pelaksanaan tugas yang seharusnya menurut ketentuan yang berlaku. Adanya ketidaksamaan antara yang telah dilaksanakan dengan yang seharusnya, ini memberikan tanda bahwa ada masalah dalam pelaksanaan tugas tersebut. Dari beberapa masalah yang ada, dipilih masalah yang prioritas untuk dicari solusi pemecahannya sebagai Inovasi yang dikenal sebagai Proyek Perubahan.

Dari hasil analisis data, diketahui variabel peran mentor pada kategori baik yang ditunjukkan dengan nilai rata-rata sebesar 3,08 hal ini menunjukkan peran metor sangat menentukan kualitas inovasi Alumni Diklatpim dalam nenunjang kinerja Pemerintah Daerah Provinsi Sulawesi Tenggara.

\section{Pengaruh Peran Coach Terhadap Inovasi}

Berdasarkan hasil analisis data dalam penelitian ini, diperoleh nilai koefisien regresi yang menunjukkan pengaruh peran coach terhadap inovasi Alumni Diklatpim dalam mendukung kinerja organisasi Perangkat Daerah Provinsi Sulawesi Tenggara yang bertanda positif dengan nilai koefisien regresi sebesar 0,19 .

Ini menunjukkan bahwa peningkatan peran coach akan dapat mempengaruhi inovasi Alumni Diklatpim dalam mendukung kinerja organisasi Perangkat Daerah Provinsi Sulawesi Tenggara. Arah dan signifikansi pengaruh peran coach terhadap inovasi Alumni Diklatpim dalam mendukung kinerja organisasi Perangkat Daerah Provinsi Sulawesi Tenggara tersebut mengindikasikan bahwa peran coach sebagai salah satu elemen yang dapat dikelola oleh manajemen yang memiliki pengaruh signifikan terhadap inovasi Alumni Diklatpim dalam mendukung kinerja organisasi Perangkat Daerah Provinsi Sulawesi Tenggara.

Coach adalah orang yang melakukan proses coaching, seorang coach akan melaksanakan proses coaching hanya akan bertanya dan menggali permasalahan coachee-nya bahkan tidak memberikan saran dan masukan, semua ide dan pemikiran berasal dari coachee-nya. Coach hanya membantu coachee-nya berpikir, menimbulkan insight dan menstrukturkan pemikiran mereka disamping itu memastikan si coachee-nya melakukan apa yang telah dia pikirkan dan katakan.

\section{Pengaruh Dukungan Stakeholder Terhadap Inovasi}

Berdasarkan hasil analisis data dalam penelitian ini, diperoleh nilai koefisien regresi yang menunjukkan pengaruh dukungan stakeholder terhadap inovasi Alumni Diklatpim dalam mendukung kinerja organisasi Perangkat Daerah Provinsi Sulawesi Tenggara yang bertanda positif namun tidak signifikan dengan nilai koefien regresi sebesar 0,03. Ini menunjukkan bahwa peningkatan dukungan stakeholder tidak berpengaruh nyata terhadap inovasi Alumni Diklatpim dalam mendukung kinerja organisasi Perangkat Daerah Provinsi Sulawesi Tenggara.

Stakeholders adalah semua pihak di dalam masyarakat, baik itu individu, komunitas atau kelompok masyarakat yang memiliki hubungan dan kepentingan terhadap sebuah organisasi yang memiliki permasalahan yang sedang diangkat, stakeholders adalah bagian penting dari organisasi yang memiliki arti terjemahan bahasa Indonesia sebagai pemangku kepentingan atau pihak yang berkepentingan.

Dalam menjamin keberlanjutan 
inovasi Alumni Diklatpim dukungan Stakeholders sangat dibutuhkan utamanya pencapaian tujuan jangka menengah dan tujuan jangka panjang, besar kecilnya dukungan yang bersumber dari stakeholder mempengaruhi keberhasilan target tujuan yang ditetapkan. Namun dalam penelitian ini dukungan stakeholder memiliki pengaruh tetapi tidak siginifikan, hal ini sebabkan inovasi yang dihasilkan Alumni Diklatpim tidak memiliki hubungan dan kepentingan/nilai manfaat yang dapat dirasakan stakeholders dengan inovasi tersebut, sebagaimana yang dikemukakan oleh Freeman (1981; 75-88), hal ini dapat kita lihat dari hasil analisis koefisien regresi 0,030 dengan siginifikansi 0,69.

\section{Pengaruh Dukungan Pemda Terhadap Inovasi}

Berdasarkan hasil analisis data dalam penelitian ini, diperoleh nilai koefisien regresi yang menunjukkan pengaruh dukungan pemda terhadap inovasi Alumni Diklatpim dalam mendukung kinerja organisasi Perangkat Daerah Provinsi Sulawesi Tenggara yang bertanda positif. Ini menunjukkan bahwa peningkatan dukungan pemda akan dapat mempengaruhi inovasi Alumni Diklatpim dalam mendukung kinerja organisasi Perangkat Daerah Provinsi Sulawesi Tenggara.

Arah dan signifikansi pengaruh dukungan Pemda terhadap inovasi Alumni Diklatpim dalam mendukung kinerja organisasi Perangkat Daerah Provinsi Sulawesi Tenggara tersebut mengindikasikan bahwa dukungan pemdasebagai salah satu elemen yang dapat dikelola oleh manajemen yang memiliki pengaruh signifikan terhadap inovasi Alumni Diklatpim dalam mendukung kinerja organisasi Perangkat Daerah Provinsi Sulawesi Tenggara.

Dukungan Pemda adalah fasilitas yang diberikan kepada Aparatur Sipil Negara atau Calon Pegawai Negeri Sipil agar dapat bekerja optimal dan memperlihatkan prestasi sesuai Tugas Pokok dan Fungsinya sehingga dapat berkontribusi terhadap kinerja penyelenggaraan pemerintahan daerah.
Fasilitas tersebut dapat berupa: sarana dan prasarana kerja, pemberian penghargaan dan hak peningkatan karir, dan tak kalah pentingnya adalah dukungan pemberian anggaran yang sangat menentukan keberlanjutan sebuah Proyek Perubahan.

\section{KESIMPULAN}

Berdasarkan hasil temuan penelitian, rumusan masalah, tujuan penelitian, hipotesis penelitian, hasil analisis data dan pembahasan hasil penelitian, dapat dikemukakan kesimpulan penelitian ini sebagai berikut:

1.Peran mentor, peran coach, dukungan stakeholder dan dukungan Pemerintah Daerah berpengaruh positif dan signifikan terhadap inovasi Alumni Diklatpim dalam mendukung kinerja organisasi Perangkat Daerah Provinsi Sulawesi Tenggara. Semakin baik peran mentor, peran coach, dukungan stakeholder dan dukungan Pemerintah Daerah maka semakin baik pula implementasi inovasi Alumni Diklatpim dalam mendukung kinerja organisasi Perangkat Daerah Provinsi Sulawesi Tenggara.

2.Peran mentor berpengaruh positif dan signifikan terhadap inovasi Alumni Diklatpim dalam mendukung kinerja organisasi Perangkat Daerah Provinsi Sulawesi Tenggara. Semakin baik peran mentor maka semakin tinggi pula inovasi Alumni Diklatpim dalam mendukung kinerja organisasi Perangkat Daerah Provinsi Sulawesi Tenggara.

3.Peran coach berpengaruh positif dan signifikan terhadap inovasi Alumni Diklatpim dalam mendukung kinerja organisasi Perangkat Daerah Provinsi Sulawesi Tenggara. Semakin baik peran coach maka semakin tinggi pula kualitas inovasi Alumni Diklatpim dalam mendukung kinerja organisasi Perangkat Daerah Provinsi Sulawesi Tenggara.

4.Dukungan stakeholder berpengaruh positif namun tidak signifikan terhadap inovasi Alumni Diklatpim dalam mendukung kinerja organisasi Perangkat Daerah Provinsi Sulawesi Tenggara. Hal ini menunjukkan bahwa dukungan stakeholder tidak berpengaruh nyata atau 
secara langsung terhadap inovasi Alumni Diklatpim dalam mendukung kinerja organisasi Perangkat Daerah Provinsi Sulawesi Tenggara.

5.Dukungan Pemerintah Daerah berpengaruh positif dan signifikan terhadap inovasi Alumni Diklatpim dalam mendukung kinerja organisasi Perangkat Daerah Provinsi Sulawesi Tenggara. Semakin baik dukungan pemda maka semakin tinggi pula inovasi Alumni Diklatpim dalam mendukung kinerja organisasi Perangkat Daerah Provinsi Sulawesi Tenggara.

6.Peran mentor merupakan faktor yang paling berpengaruh terhadap inovasi Alumni Diklatpim dalam mendukung kinerja organisasi Perangkat Daerah Provinsi Sulawesi Tenggara.

\section{REKOMENDASI}

Berdasarkan hasil analisis data, pembahasan dan kesimpulan penelitian ini, maka rekomenasi yang dapat dikemukakan adalah:

1.Coach senantiasa membimbing Alumni Diklatpim menemu-kenali isu yang ada dalam pelaksanaan tugas pokok dan fungsinya, memunculkan ide inovasi yang bermanfaat sehingga menentukan kualitas inovasi yang dihasilkan oleh alumni Diklatpim, maka peran Coach perlu didorong terus menerus ke arah yang lebih baik.

2.Peran Mentor perlu terus dioptomalkan dalam mendukung Inovasi Alumni Diklatpim dalam penetapan dan implementasi proyek perubahan peserta Diklatpim sehingga inovasi yang disusun Alumni Diklatpim benar- benar dapat memberikan manfaat dalam mendukung dan meningkatkan kinerja Organisasi Perangkat Daerah Provinsi Sulawesi Tenggara. Perlu dipertahankan pelaksanaan peran mentor khususnya dalam penentuan tema Proyek Perubahan, bahkan jika mungkin dapat ditingkatkan

3.Mengingat peran stakeholders berdasarkan hasil penelitian kurang siginifikan terhadap inovasi dalam mendorong implementasi inovasi Alumni Diklatpim khususnya pada jangka menengah dan panjang maka diperlukan strategi komunikasi yang tepat dalam melakukan komunikasi dengan stakeholder sehingga mereka dapat menerima dan mendukung, bahkan bila memungkikan dibangun komunikasi antar stakeholder agar inovasi yang dihasilkan dapat dijalankan bersama.

4.Dukungan Pemerintah Daerah terhadap Inovasi terkait dengan pengalokasian anggaran dalam mengimplementasikan tujuan jangka menengah dan jangka panjang perlu menjadi perhatian untuk didorong kearah lebih baik.

5.Khusus Alumni Diklatpim diharapkan mampu terus membangun komunikasi yang baik dengan stakeholders dan mengajak/mempengaruhi mereka untuk terlibat bersama sama dalam mengimplementasikan Inovasi/Proyek Perubahan yang dihasilkan.

\section{REFERENSI}

Azwar, Saifudin, 2003. Sikap Manusia Teori dan Pengukurannya Yogyakarta Pustaka Pelajar.

Sahabuddin, 2019. Peran Integritas ASN dan Pembangunan Karakter dalam era industri 4.1 Kendari : Media Nusa Creative

Arikunto, S 2006. Presedur Penelitian Suatu PebdekatanPraktek Jakarta: Rineka Cipta

Creswell, John W 1994. Research Design Qualtative and Quantitative Approaches. Sage Publication International Educatiobnal and Profesional Publisher. Thousand Oaks. London-New Delhi.

Sugiyono, 2016, Metode Penelitian Kuantitatif, Kualitatif dan $R \& D$ Jakarta Alfabeta

Effendi, Sofyan dan Singaribuan Masri 1990.Methodologi Penelitian survey, LP3S, Jakarta

Abidin, Said Zainal. 2002.Kebijakan Publik. Jakarta:Yayasan Pancur Siwah. 
Birkland, Thomas A. 2005. An Introduction Policy Process, Theories, Concept, and odels of Public Policy Making. New York:M.E. Sharpe, Inc.

Bungin, Burhan.2007. Penelitian Kualitatif, Komunikasi, Ekonomi, Kebijakan Publik dan Ilmu Sosial Lainnya. Jakarta: Prenada Media Group.

Creswell, John W. 2009.Research Design, Qualitative, Quantitative, and Mixed Methods Approach. USA: SAGE.

Denzin, Norman K. and Yvonna s. Lincoln, Ed. 1994. Handbook of Qualitative Research.Sage Publication.

Dunn, William N. 2003.Pengantar Analisis Kebijakan Publik Edisi Kedua. Yogyakarta: Gadjah Mada University Press.

Dye, Thomas. 1987.Understanding Public Policy. Florida State University.

Edward, George and Ira Sharkansky.1978.The Policy Predicament, Making and Implementing Public Policy. San Francisco:W.H. Freeman and Company.

Garna. Judistira K. 2007. Metoda Penelitian Pendekatan Kualitatif.Bandung: Primaco Akademica and Judistira Garna Foundation.

Howlett, Michael and M. Ramesh. 1955. Studying Public Policy: Policy Cycless abd Policy Subsystems. Toronto: Oxford University Press.

Islamy, $\quad$ Irfan.2009.Prinsip-prinsip Perumusan Kebijaksanaan Negara. Jakarta:Buki Aksara

Jones, Charles O. 1994. Pengantar Kebijakan Publik (Public Policy) Jakarta: PT Raja Grafindo Persada.

Kartiwa, A dan Nugraha.2012. Mengelola Kewenangan Pemerintahan.
Kusumanegara, Solahudin. 2010. Model dan Aktor Dalam Proses Kebijakan Publik. Yogyakarta: Gava Media.

Moleong, Lexy J. 2012.Metode Penelitian Kualitatif.Bandung: Remaja Rosdakarya Nugroho, Riant.2004. Kebijakan Publik. Formulasi, Implementasi dan Evaluasi. Jakarta: Elex Media Komputerindo.

2006. Kebijakan Publik untuk Negara-Negara Berkembang. Model -model Perumusan, Implementasi dan Evaluasi. Jakarta: Elex Media Komputerindo.

2012. Publik Policy. Jakarta: Elex Media Komputerindo.

Parsons, Wayne.2005. Public Policy. Pengantar Teori dan Praktek Analisis Kebijakan.Jakarta: Prenada Media.

Purwanto, Erwan Agus dan Dyah Ratih Sulistyastuti.2012. Implementasi Kebijakan Publik. Konsep dan Aplikasinya Di Indonesia. Yogyakarta: Gava Media.

Sedarmayanti. 2010.Reformasi Administrasi Publik, Refornasi Birokrasi, dan Kepemimpinan Masa Depan (Mewujudkan Pelayanan Prima dan Kepemerintahan Yang Baik).Bandung:Refika Aditama.

Simon, Christopher A. 1968. Public Policy: Preference and Outcome. New York: Pearson Education.

Subarsono, AG.2008. Analisis Kebijakan Publik. Konsep, Teori dan Aplikasi. Yogyakarta: Pustaka Pelajar.

Sugiyono. 2008. Metode Penelitian Pendidik Pendekatan Kuantitatif, Kualitatif dan $R \& D$ Bandung : Alfabeta.

Lembaga Admnistrasi Negara RI, 2019, Kajian Evaluasi Pasca Diklat Kepemimpinan Tingkat II, III dan IV 